\title{
Testing the Use of Coconut Fiber as a Cushioning Material for Transport Packaging
}

\author{
Clívia D. Pinho da Costa Castro ${ }^{1}$, José de Assis Fonseca Faria ${ }^{1}$, Tiago Bassani Hellmeister Dantas ${ }^{2}$ \\ ${ }^{1}$ Faculty of Food Engineering, University of Campinas-UNICAMP, Campinas, Brazil; ${ }^{2}$ Centre for Packaging Technology-ITAL, \\ Campinas, Brazil. \\ Email: assis@fea.unicamp.br
}

Received December 21 ${ }^{\text {st }}$, 2011; revised January $17^{\text {th }}$, 2012; accepted February $21^{\text {st }}, 2012$

\begin{abstract}
In spite of being a raw material of virtually unlimited availability due to the massive consumption of the highly popular coconut water, fiber produced from green coconut is much less used than the dried coconut fiber. The objective of this study was to investigate the performance of green (white) coconut fiber as a cushioning material for use in packaging systems. The mechanical performance of both green coconut fibers in their natural state as well as those molded into the shape of cushioning pads were evaluated by shock absorption tests. The results showed that the fibers without agglutination agents exhibited the best performance when submitted to increasing static loads by presenting the greatest capacity to reduce impact acceleration. In addition, green coconut fiber presented behavior similar to that of cellulosic cushioning materials and in certain situations can be considered effective in protecting products that are considered fragile.
\end{abstract}

Keywords: Coconut Fiber; Impact; Cushioning

\section{Introduction}

Among vegetable fibers, coconut fiber (Cocos nucifera) has been extensively used in the development of ecological products, probably due to its characteristic as organic solid waste. Within this context, the traditional making of ropes, brushes, carpets, mats, and more recently, the manufacture of automotive components and gardening products, all of which generally use the dried fibers of mature coconut molded with vulcanized rubber. However, large volumes of post-consumer white coconut fibers pose enormous ecological problems-particularly in large urban centers where they are generated as solid waste by coconut water processing industries-and for which, so far, only very few applications have been evaluated. On the other hand, even being available in huge quantities as a result of the increasing consumption of coconut water, green (white) coconut fiber has not established itself on the Brazilian market as a raw material source. A recent survey estimated that in 2008 approximately 2.5 million metric tons of coconut husks were generated in Brazil [1]. However, of the total amount of coconuts harvested in the world, only $15 \%$ of the fibers are put to good use [2].

The lack of knowledge concerning the properties of white coconut fiber is the reason why it is much less used compared to the mature coconut husk fiber [3]. For that reason, a viable alternative would be the use of coconut fiber as a protective material in packaging systems. Though some studies do mention this possibility [4,5], no research studies were found in the literature on the cushioning properties of this material or of any other potential applications.

In cushioning systems, the use of cellulosic materials has been common practice for quite some time; however, the preference for plastic materials in the cushioning segment is related to the level of protection of the product provided per amount of material and also by its resilience properties. In a comparative study [6], concluded that plastic materials provide better protection for a smaller amount of material compared to non-plastic materials. Furthermore, plastic materials are not affected by moisture, are decomposition-resistant and resist fungal growth. However, ecological requirements have been encouraging reducing the amounts of plastic materials used in the manufacturing of packagings, as well as research and development of alternative materials and technologies. Within this context, based on the results of mechanical tests, this study investigates the levels of protection that can be provided by coconut fiber, both when used in its natural form and as molded into cushioning pads with the aid of natural agglutination agents.

\section{Experimental}

\subsection{Material}

The raw materials used were: 1) green coconut husk was 
used to obtain fibers; 2) natural agglutination agents were used to shape and mold the coconut fibers pads.

The fibers were obtained by a mechanical de-husking process of the husk coconut, which is a post-consumer waste product after the extraction of coconut water, a popular thirst quencher consumed in urban settings such as kiosks and leisure areas located in the city of Campinas, SP, Brazil.

For the manufacture of pads were used as agglutination the following agents: centrifuged natural rubber latex, supplied by Braslátex Ind. e Com. de Borrachas Ltda, Bálsamo-SP and cassava starch purchased from a local retail outlet in Campinas, SP, Brazil.

\subsection{Methods}

\subsubsection{Extraction of Coconut Fiber from the Fruit Husk by Mechanical Defibration}

After harvesting, the whole coconut husks were first passed through a dry pre-cleaning process and then defibrated by a mechanical process, that is, without previous crushing of the husks into fragments [7,8]. Basically, the process use a rotating machine where the coconut husk are exposed to high impact in order to disintegrate the husk into fiber and dust. After disintegration the fibers were separated from the coconut dust by using a rotary sieve and subsequently sun dried to a final a moisture content of $15 \%$.

\subsubsection{Evaluation of the Coconut Fiber}

Whereas the aim of the defibration was to obtain long fibers in order to obtain a better cushioning performance, the length of one hundred individual fibers was measured at room temperature $26^{\circ} \mathrm{C} \pm 2^{\circ} \mathrm{C}$ by using a caliper with accuracy of $1 \mathrm{~mm}$ [2].

\subsubsection{Preparation of the Test Specimens of Coconut Fiber}

The coconut fibers were used to make test specimens that subsequently were used for shock absorption testing. Two types of test specimen were obtained: 1) fiber in their natural way or without using any additive; 2 ) fiber pads bonded with natural agglutination agents.

Test specimens of fiber pads without additive: considering the difficulty to determine the thickness of bulk materials, it was decided to evaluate the materials as a function of their weight and not based on the thickness, as would be usual. Thus, test specimens with masses of $0.025 \mathrm{~kg}, 0.050 \mathrm{~kg}, 0.075 \mathrm{~kg}$ e $0.100 \mathrm{~kg}$ of fiber, were weighed in a semi-analytical balance.

Test specimens of fiber pads with agglutination agents: it was prepared by varying the thickness of the test specimen $(0.025 \mathrm{~m}$ and $0.050 \mathrm{~m})$ and the type of agglutination agent (latex and starch). All cushioning pads were molded to the same mass $(0.050 \mathrm{~kg}$ for $0.025 \mathrm{~m}$ and $0.100 \mathrm{~kg}$ for $0.050 \mathrm{~m}$ ) and same shape of the test specimens $(0.2 \times 0.2 \mathrm{~mm})$. For this, the fibers were molded in a cardboard box containing the dimensions of the test specimen. During the preparation of the pads containing agglutinant the latex was diluted with water up to a ratio of $5 \%$ rubber solids. The agglutinants were sprayed onto the fibers using a pneumatic pulverizer. The material was deposited into a mold of suitable size and shape and the resulting pads were dried in the sun during 30 minutes followed by the removal of mold and dry the pads up to a moisture content of $15 \%$. For the pads with starch, the gel was adjusted to contain $5 \%$ starch by heating with water at $80^{\circ} \mathrm{C}$. As previously, the agglutinant was sprayed onto the fibers, molded and dried in sun [7].

All test specimens were conditioned for 48 hours in a room with conditioning atmosphere at $23^{\circ} \mathrm{C} \pm 1^{\circ} \mathrm{C}$ e $50 \% \pm$ $2 \% \mathrm{RH}$, until the time of impact test based on the principles and guidelines of ASTM Standard Test Method D 685 (1993).

\subsubsection{Shock Absorption Test}

The impact absorption capacity of the coconut fiber was evaluated using a shock absorption test based on the principles and guidelines of ASTM Standard Test Method D 4168 (2002). In this test, wooden boards were used as static load subjected to vertical free fall under the coconut fibers pads in order to assess the ability of fiber to slow the impact. The drop testing equipment used included a MTS Model 868 Shock Absorber Test System, a PCB model 8626M01 accelerometer, attached to the shock absorber bench; a Dytran model 3105A accelerometer, attached to wooden boards used as static load; and a wooden box used as a support for the samples. Signal analysis was performed with the GHI Wincat sofware program (version 2.00), using a $500 \mathrm{~Hz}$ filter.

The tests were performed in two stages. In the first stage, the test specimens consisting of coconut fibers pads without additive; and in the second stage, test specimens consisting of coconut fibers pads with agglutination agents. All tests were conducted at room temperature $21^{\circ} \mathrm{C} \pm 2{ }^{\circ} \mathrm{C}$ and relative humidity of $60 \% \pm 3 \%$.

To assess the performance of the natural coconut fiber, the drop height was $0.30 \mathrm{~m}$ and the following variables were selected: 1) Static pressure varying from 0.11 to $0.94 \mathrm{kPa}$, a range which falls into the category classified as "light" [9]; 2) mass of test specimen varying from 0.025 to $0.100 \mathrm{~kg}$. Under these conditions forty trials were performed in triplicate, as planned in Table 1. After these tests, evaluated the best points of the curve on the level of protection and the tests were repeated for a drop height standard of $0.75 \mathrm{~m}$. Thus was possible estimate the loss of thickness of each specimen immediately after the shock absorption. 
To assess the performance of the coconut fiber pads using agglutination agents, the other parameters were the same as the previous plan, but only five values were applied static pressure, as shown in Table 2.

\section{Results and Discussion}

\subsection{Evaluation of Coconut Fiber}

The fact that the coconut husk did not have to be previously crushed, not only speeded up the defibration process and made it more agile, it also produced a greater proportion of long fibers, with an average length of $153 \pm$ $49 \mathrm{~mm}$. With the defibration process, white fibers are obtained which turn brown during drying due to the action of polyphenol oxidase. This enzyme is commonly found in fruits and vegetables and promotes aerobic oxidation of a variety of phenolic substrates [10]. Its action resulted in the formation of brown fibers, due to the rupture of tissue (husk) during defibration and contact with ambient air during drying (Figure 1).

\subsection{Shock Absorption Behavior of Coconut Fiber Pad without Agglutinants}

The results of the shock absorption test are presented in

Table 1. Planning of shock absorption test using coconut fibers without agglutinants, as static pressure and mass of test specimen.

\begin{tabular}{cccccccccccc}
\hline \multirow{2}{*}{ Mass (kg) } & \multicolumn{10}{c}{ Static (kPa) } \\
\cline { 2 - 11 } & 0.11 & 0.18 & 0.28 & 0.38 & 0.48 & 0.55 & 0.65 & 0.74 & 0.84 & 0.94 \\
\hline 0.025 & 1 & 2 & 3 & 4 & 5 & 6 & 7 & 8 & 9 & 10 \\
0.050 & 11 & 12 & 13 & 14 & 15 & 16 & 17 & 18 & 19 & 20 \\
0.075 & 21 & 22 & 23 & 24 & 25 & 26 & 27 & 28 & 29 & 30 \\
0.100 & 31 & 32 & 33 & 34 & 35 & 36 & 37 & 38 & 39 & 40 \\
\hline
\end{tabular}

Table 2. Planning of shock absorption test using coconut fibers with agglutinants, as static pressure and thickness of test specimen.

\begin{tabular}{cccccc}
\hline \multirow{2}{*}{ Thickness (m) } & \multicolumn{5}{c}{ Static $(\mathrm{kPa})$} \\
\cline { 2 - 6 } & 0.11 & 0.18 & 0.28 & 0.38 & 0.48 \\
\hline 0.025 & 1 & 2 & 3 & 4 & 5 \\
0.050 & 6 & 7 & 8 & 9 & 10 \\
\hline
\end{tabular}

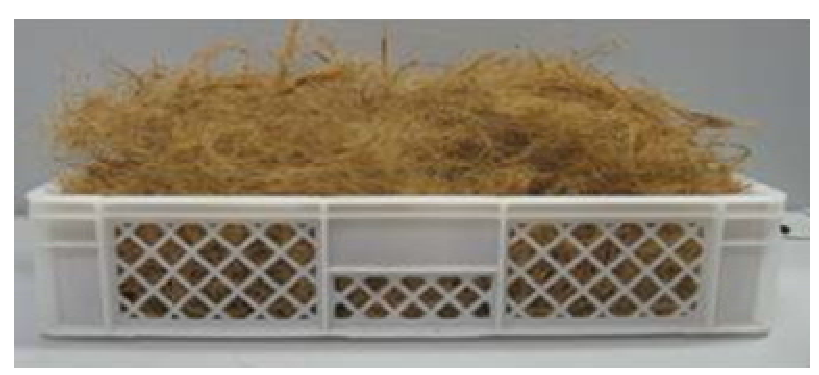

Figure 1. Coconut fiber after mechanical defibration. the Figures 2 and 3, that is, deceleration peaks on the vertical axis and static load on the horizontal axis. Figure 2 shows the behavior of natural coconut fiber using test specimens of fiber pads without additive with four different weights, static charge in the range from 0.11 to $0.94 \mathrm{kPa}$ and drop height of $0.30 \mathrm{~m}$. Under these conditions, all curves showed an increase of slowing up with increasing static load, except at the point of $0.55 \mathrm{kPa}$, where there is a sharp drop of the slowdown in the four test specimens. This behavior highlights best level of protection compared to $0.55 \mathrm{kPa}$ at higher loads, however would need further study load in less than $0.55 \mathrm{kPa}$. Also in Figure 2, it was observed that after $0.65 \mathrm{kPa}$, most of the curves showed a mixed but tending to the gradual reduction in the levels of deceleration, as increased static charge. This observation could not be extended to the curve of $0.025 \mathrm{~kg}$, because the material had very high level of deceleration, making it impractical to continue testing.

When evaluating the individual performance of the curves in Figure 3 and compare them to the critical acceleration of some products [11], evidences that coconut fiber pads without additives was effective to protect

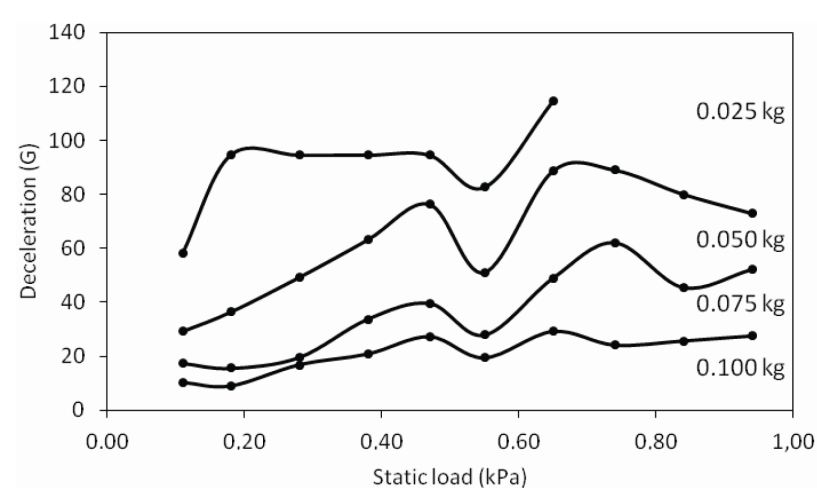

Figure 2. Performance of coconut fiber pad without agglutinants subjected to drop testing; means of three cumulative impacts, drop height of $0.30 \mathrm{~m}$, in the static load range between $0.11-0.94 \mathrm{kPa}$, at $21^{\circ} \mathrm{C} \pm 2^{\circ} \mathrm{C}$ e $60 \% \pm 3 \% \mathrm{RH}$.

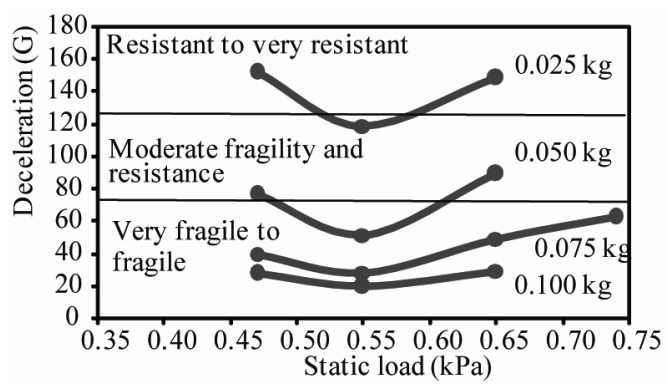

Figure 3. Performance of coconut fiber pad without agglutinants subjected to drop testing and correlation with product resistances: means of three cumulative impacts from a drop height $0.30 \mathrm{~m}$, in the static load range between 0.47 $0.75 \mathrm{kPa}$; at $21^{\circ} \mathrm{C} \pm 2^{\circ} \mathrm{C}$ e $60 \% \pm 3 \% \mathrm{RH}$. 
products with fragility levels lower than $40 \mathrm{G}$, provided that the drop conditions of the 0.075 and $0.100 \mathrm{~kg}$ are used, which are capable of decelerating the impact of a load of $0.55 \mathrm{kPa}$ to 28 and $19 \mathrm{G}$, respectively. Theoretically, coconut fiber pads without additive, when used in small quantities such as in the curves at $0.025 \mathrm{~kg}$ and $0.050 \mathrm{~kg}$, could only be used for protecting robust products such as machinery and tools with critical acceleration above $100 \mathrm{G}$ [12].

In this way, it was found that coconut fiber might be effective in protecting fragile products ( $\mathrm{G}$ factor $<60$ ); including apples which, according to [13], have a critical acceleration value greater than 78 G. However, it is necessary to emphasize that this condition is applicable only to drop heights no greater than $0.30 \mathrm{~m}$ and to products with a low weight $x$ surface area ratio $(0.55 \mathrm{kPa})$. In practice, this means that a product with a fragility of 60 $\mathrm{G}$ and weighing approximately $0.560 \mathrm{~kg}$ should occupy an area of $0.01 \mathrm{~m}^{2}$ on the fiber to ensure that, when falling from a height of $0.30 \mathrm{~m}$, deceleration after impact would not exceed $60 \mathrm{G}$. In this situation, $0.05 \mathrm{~kg}$ of the coconut fiber distributed over a surface area of $0.04 \mathrm{~m}^{2}$ would provide a deceleration of $51 \mathrm{G}$, and for that reason, would be not only the more economical option, but also, and the same time, offer more effective protection to this hypothetical product.

For a drop height of $0.75 \mathrm{~m}$, the results of the $0.075 \mathrm{~kg}$ and $0.100 \mathrm{~kg}$ curves are depicted in Figure 4. It can be observed that loose coconut fiber presented a pronounced reduction in deceleration capacity, due to the increased drop height. However, for the condition of the $0.100 \mathrm{~kg}$ curve, it still proves to be effective to protect products considered fragile. During this test, it was possible to estimate the loss in thickness of the coconut fiber after successive impacts, with the loose fibers showing a loss of more than 10\%, as can be seen in Figures 5 and $\mathbf{6}$. In comparison, it can be seen that the static load of $0.55 \mathrm{kPa}$ caused a greater loss in thickness for lower deceleration values, both for the $0.075 \mathrm{~kg}$ curve as for the $0.100 \mathrm{~kg}$ curve. This behaviour occurred due to the energy impact to be absorbed by the cushioning, thereby causing the

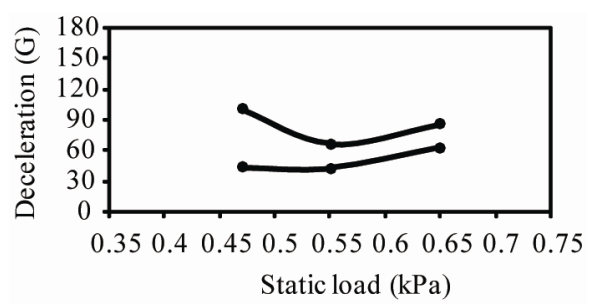

Figure 4. Performance of coconut fiber pad without agglutinants relative to the protection of products with varying degrees of resistance: means of three cumulative impacts from a drop height of of $0.75 \mathrm{~m}$, in the static load range between $0.47-0.75 \mathrm{kPa}$, at $21^{\circ} \mathrm{C} \pm 2^{\circ} \mathrm{C}$ e $60 \% \pm 3 \% \mathrm{UR}$. deformation of the material. However, it would be interesting to evaluate the loss of thickness of the pad caused over time under load creep tests, because a smaller thickness may be insufficient to protect it from shocks [14, 15].

\subsection{Evaluation of the Process of Obtaining Coconut Fiber Pads}

As for the fiber pads with agglutination agents (Figure 7), its process of obtainment was favored by the ease molding of the fiber. It was observed that the fibers take on the desired shape by simple hand pressure, which greatly

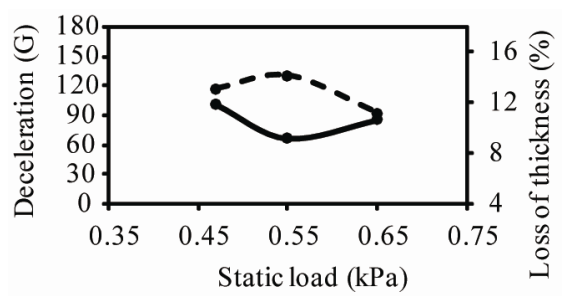

Figure 5. Means of the deceleration and loss of thickness of coconut fiber pad without agglutinants with initial mass of $75 \mathrm{~g}$, after three cumulative drop impacts from a drop height of $0.75 \mathrm{~m}$, in the $0.47-0.75 \mathrm{kPa}$ static load range, at $21^{\circ} \mathrm{C} \pm 2^{\circ} \mathrm{C}$ e $60 \pm 3 \%$ UR.

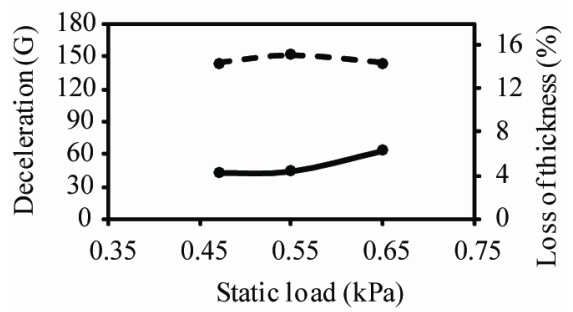

Figure 6. Means of the deceleration and loss of thickness of coconut fiber pad without agglutinants with initial mass of $100 \mathrm{~g}$, after three cumulative drop impacts from a drop height of $0.75 \mathrm{~m}$, in the $0.47-0.75 \mathrm{kPa}$ static load range, at $21^{\circ} \mathrm{C} \pm 2^{\circ} \mathrm{C}$ e $60 \% \pm 3 \%$ UR.

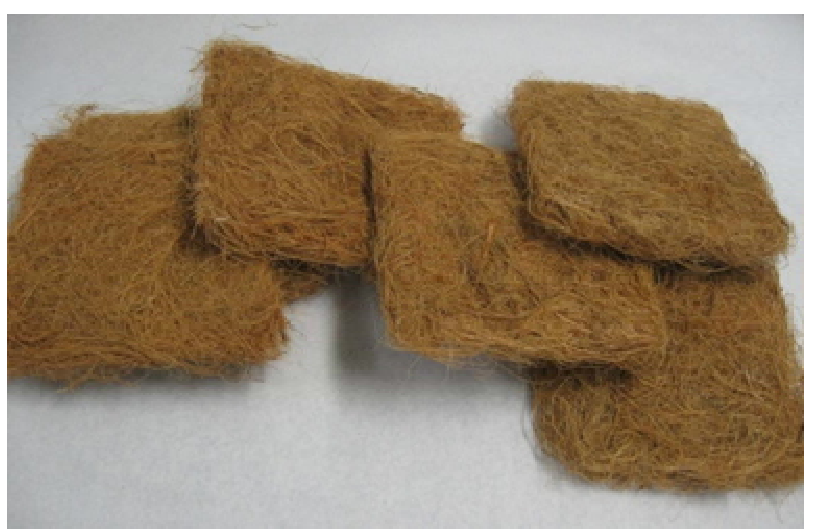

Figure 7. Cushioning pads made of coconut fiber, starch and latex. 
facilitated the molding of the pads. In spite of the fact that the agglutinants had been applied under pressure onto the fibers, it was noticed that after drying, the starch gel and diluted latex were found to be present for the most part only at the outer surface of the pads.

The use of agglutinants and the molding process used did not favor natural agglomeration of the fibers, but instead lead to compaction of the pads, eliminating the voids or empty spaces between the fibers which provide resilience to the material. According to [16], cushioning resilience depends on the orientation of the fibers and, when fibers are rolled up, frayed and tangled up, this procedure results in better cushioning properties due to its greater resilience, once the fiber is aligned in the same direction in which the force is applied.

\subsection{Behavior under Shock of Coconut Fiber Pads}

The results reveal that the use of agglutinants did not contribute to increasing the performance of the fiber pads as cushioning material. As for the molded coconut fiber, the curves of each type of material are compared in Figures 8 and 9, for a static load ranging from 0.11 to 0.48 $\mathrm{kPa}$, and thickness of $0.025 \mathrm{~m}$ and $0.050 \mathrm{~m}$, respectively. Among the pads evaluated, fibers without added agglutinants stood out as having better performance than the other alternatives tested, in view of the fact that with increasing static load, they exhibited the greatest capacity to reduce impact acceleration.

As for the pads formed using latex, higher acceleration values were observed, probably because the fibers embedded in or covered by vulcanized rubber are less effec-

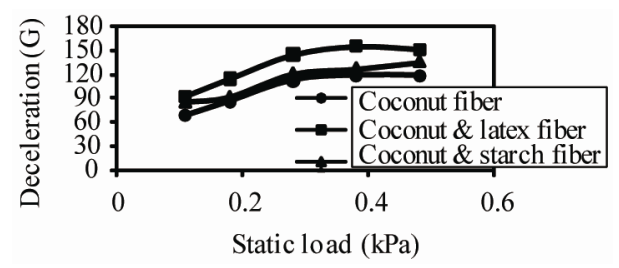

Figure 8. Comparison between the shock test results for pads of $\mathbf{0 . 0 2 5} \mathbf{m}$ thickness and made of fibrous material for a drop height of $0.30 \mathrm{~m}$, in the $0.11-0.48 \mathrm{kPa}$ static load range at $21^{\circ} \mathrm{C} \pm 2^{\circ} \mathrm{C}$ e $60 \% \pm 3 \% \mathrm{UR}$.

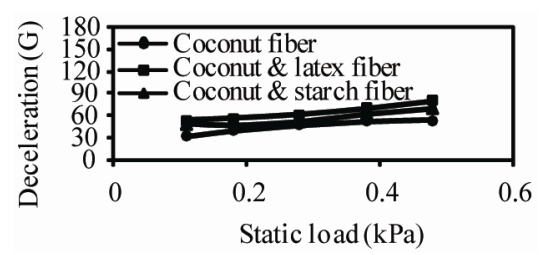

Figure 9. Comparison between the shock test results for pads of $\mathbf{0 . 0 5 0} \mathbf{m}$ thickness and made of fibrous material for a drop height of $0.30 \mathrm{~m}$, in the $0.11-0.48 \mathrm{kPa}$ static load range at $21^{\circ} \mathrm{C} \pm 2^{\circ} \mathrm{C}$ e $60 \% \pm 3 \% \mathrm{UR}$. tive for cushioning purposes [4]. As for the starch gel, there was a behavior similar to latex. However, it is important emphasize that the addition of plasticizer(s) to the starch gel could provide greater malleability after drying [17], and maybe lead coconut fiber to producing better results.

\section{Conclusion}

Based on the shock tests it was concluded that coconut fiber as tested in its natural form presented better cushioning effect as compared to pads of fiber molded with agglutinants. The cushioning effect of the fiber was enhanced because of the higher length of the fiber produced from the green coconut husk. However, the use of agglutination agents increase the possibilities for use of coir as an alternative cushioning material since they facilitate handling and may improve the resilience of pads.

\section{Acknowledgements}

The authors gratefully acknowledge the research funds from Fundação de Amparo à Pesquisa do Estado de São Paulo (FAPESP) and the scholarship from Conselho Nacional de Desenvolvimento Científico e Tecnológico (CNPq).

\section{REFERENCES}

[1] Food and Agriculture Organization of the United Nations (FAO), 2009. http://faostat.fao.orgr

[2] W. Wei and H. Gu, "Characterisation and Utilization of Natural Coconut Fibres Composites,” Materials and Design, Vol. 30, No. 7, 2009, pp. 2741-2744. doi:10.1016/j.matdes.2008.11.002

[3] E. Corradini, M. de F. Rosa, B. P. de Macedo, P. D. Paladin and L. H. C. Mattoso, "Composição Química, Propriedades Mecânicas e Térmicas da Fibra de Frutos de Cultivares de Coco Verde,” Revista Brasileira de Fruticultura, Vol. 31, No. 3, 2009, pp. 837-846.

[4] B. E. Grimwood, "Coconut Palm Products: Their Processing in Developing Countries," Food and Agriculture Organization of the United Nations, Roma, 1975.

[5] D. B. Osborn, “Package Cushioning Systems,” In: F. A. Paine, Ed., Packaging Materials and Containers, Blackie and Son Ltd., London, 1967.

[6] P. Singh, N. Charnnarong and G. Burgess, "Comparison of Packaging Materials for Cushioning Based on Environmental Concerns," Proceeding of the IAPRI Congress 8th World Conference on Packaging, São Paulo, 20-23 June 1993.

[7] J. A. F. Faria, “Aplicações da Fibra de Coco Verde Como Material de Acolchoamento em Sistemas de Embalagens Para Frutas,” Projeto FAPESP, São Paulo, 2008.

[8] C. D. P. C. Castro, “Avaliação da Fibra de Coco Verde Como Material de Acolchoamento em Sistemas de Embalagens Para Mamão e Manga,” Ph.D. Thesis, Universidade Estadual 
de Campinas, Campinas, 2011.

[9] J. F. Hanlon, R. J. Kelsey and H. E. Forcinio, “Handbook of Package Engineering,” CRC Press, Boca Raton, 1998.

[10] A. W. O. Lima and P. S. Bora, "Application of a New Continuous Flow Spectrophotometric Method for the Characterization of Polyphenol Oxidase Naturally Immobilized on Coconut Fiber," Journal of Food Biochemistry, Vol. 27, No. 3, 2003, pp. 237-254.

[11] Instituto de Pesquisas Tecnológicas (IPT), "Embalagens de Transporte: Guia de Uso,” IPT, São Paulo, 1975.

[12] R. K. Brandenburg and J. J. Lee, "Fundamentals of Packaging Dynamics,” MTS System Corporation, Eden Prairie, 1988.

[13] L.-X. Lu and Z.-W. Wang, "Dropping Bruise Fragility and Bruise Boundary of Apple Fruit," Transactions of the ASABE, Vol. 50, No. 4, 2007, pp. 1323-1329.

[14] J. Marcondes, K. Hatton, J. Graham and H. Schueneman, "Effect of Temperature on the Cushioning Properties of Some Foamed Plastic Materials,” Packaging Technology and Science, Vol. 16, No. 2, 2003, pp. 69-76.

[15] A. H. Mckinlay, “Transport Packaging,” CRC Press, Boca Raton, 1999.

[16] C. G. Jarman, “A Note on Rubberized Coir,” Tropical Products Institute, London, 1969.

[17] M. F. Rosa, B.-S. Chiou and E. S. Medeiros, "Biodegradable Composites Based on Starch/EVOH/Glycerol Blends and Coconut Fibers," Journal of Applied Polymer Science, Vol. 111, No. 2, 2009, pp. 612-618. 